\title{
MoTIVÁCIÓ ÉS ÖNSZABÁLYOZÓ TANULÁS
}

\section{KATONA NóRA}

az Eötvös Loránd Tudományegyetem Pedagógiai és Pszichológiai Kar

Társadalom- és Neveléslélektani Tanszékének adjunktusa

katona.nora@ppk.elte.hu

\begin{abstract}
Az utóbbi két évtizedben az iskolai tanulás megértésében egyre nagyobb szerepet kap az a nézöpont, miként lehet az iskolai tanulást olyan folyamatként értelmezni, amelyben a tanuló aktív résztvevö. Erre jelent meg válaszként a pszichológia területén az önszabályozó tanulás elmélete. A cikk Maslow önaktualizációs elméletéből indul ki, majd az öndetermináció és az énhatékonyság motivációs szerkezetét elemzi, ezt kiegészíti az attribúciós folyamatok leirásával, a motivációs stílusokat taglalásával, az elvárásokat és a célokat számításba vevö elméletek lényegi pontjainak felvázolásával. Így jut el az önszabályozó tanulás motivációs rendszeréig rámutatva, hogy az egyes elméletek miként járultak hozzá a tervezést, az önellenörzést és az önreflexiót egyaránt figyelembe velö komplex modell kialakulásához.
\end{abstract}

Az emberi motiváció szerteágazó problémakörének megértéséhez a tanulásnak olyan felfogására támaszkodom, amely e folyamatot nem egyszerúen csak viselkedésbeli változásnak tekinti, mint ahogyan azt a korai behaviorizmus állította, és nem is csupán ismeretsémák átstrukturálásával jellemezhető, amelyet később a kognitivizmus hangsúlyozott, hanem a jelenség olyan megközelítésére, mely a személyiség különféle jellemzőit érinti és alapvető kapcsolatban áll az emberi erők kibontakozásával, a növekedéssel, valamint a fejlődési feladatok felismerésével (Smith, 1982; Houde, 2006). Az elmélyült tanulás az életkor elörehaladtával egyre inkább a személyes felelősségre épül, melynek előfeltétele, hogy az egyén nyitott legyen a változásra az ôt jellemző attitűdök, képességek, értékorientációk tekintetében. A személyiség mélystruktúráit befolyásoló biológiai és szocializációs hatóerők feltárása szükséges a változást segítő vagy azt akadályozó tényezők feltérképezéséhez, a motivált viselkedés okának, céljának megértéséhez. Ehhez azonban nem elegendő támaszkodni egy-egy szük spektrumú motivációs elméletre, hanem a mindennapi tanulási helyzetek sokrétűségéhez illeszkedő komplex fogalmi megközelítésekre van szükség.

\section{A szükségletek hierarchiája}

Az egyik legkorábbi komplex motivációelméletet Maslow hozta létre, amely a társas, érzelmi és kognitív szükségleteket egyaránt a figyelem középpontjába helyezi 
(Maslow, 1943). Maslow szerint az emberi szükségletek (fiziológiai, biztonsági, elfogadás, önbecsülés, önaktualizáció, majd intellektuális és esztétikai) hierarchikusan szerveződnek. A hierarchia alacsonyabb fokán lévő szükségletek által ösztönzött cselekvéseknek célba kell érniük ahhoz, hogy a magasabb szinten lévö szükségletek müködésbe léphessenek. Az elméletalkotó szerint a csecsemő nem él át biztonságélményt addig, amíg fiziológiai szükségletei, éhsége, szomjúsága rendszeresen nincs kielégítve. Ha a felnövekvő gyermek nem rendelkezik megfelelö önbecsüléssel, nem lesz képes arra, hogy észlelje, milyen területen vannak erős oldalai, nem tesz erőfeszítést arra, hogy különféle területeken kezdeményező legyen az önfejlesztésben, nem vállal felelősséget képességeinek kibontakoztatásáert. Jóllehet ezek az összefüggések elfogadhatónak bizonyulnak akkor, ha fiatal gyerek problémáját elemezzük, aki kevés önirányítással rendelkezik, vagy serdülö, illetve felnőtt esetén, ha egy szükséglet súlyos deprivációjáról van szó, de sokan mégis megkérdőjelezik a szükségletek lépcsőzetes kibontakozását, mert több ellentétes tendencia is igazolható (Ventegodt et al., 2003). Egy olyan szituációban, ahol az anya és gyermeke is éhezik, a gyermekét szerető anya a kevés élelmet inkább gyermekének adja, míg ő folytatja a nélkülözést. Katasztrófahelyzetben az éhséggel, szomjúsággal, fáradtsággal, hideggel szemben az életéért küzdő egyén azáltal képes napokig életben maradni, hogy fenn tudja tartani önbecsülését, és elő tudja hívni találékonyságát, kreativitását, az önaktualizáció szükségletét. Egy hétköznapi helyzetben a serdülö, hiába éhes, ha barátai nem azok, inkább ő sem megy ebédelni (kielégítve fiziológiai szükségleteit), hanem éhesen a barátaival tart, ezzel a valahová tartozás és elfogadás szükségleteit helyezi előtérbe. A motiváció megjelenésének lépcsőzetessége szempontjából ellentmondásosnak látszik a veszélyeztetett gyermekek azon csoportja, akik a gyermekbántalmazás és más negatív szocializációs hatások ellenére öngyógyító módon keverednek ki a bajokból (resilient child), proszociális készségekkel rendelkeznek, s többek között magas teljesítményt érnek el az iskolában (Strinski et al., 2000; Braverman, 2001; Kwok et al., 2007).

Az elméletről szóló kritikák azonban nem elég erősek ahhoz, hogy megingassák Maslow alapvető felismeréseit, inkább csak arra hívják fel a figyelmet, hogy a motivált viselkedés megértése során egyszerre több hatótényezővel kell számolnunk, a motívumok dominancia sorrendjét illetően pedig célravezetőnek tünik, ha azt az egyén és a családon túlmutató társas környezet kölcsönhatásának eredőjeként kezeljük. A bírálatok nem csökkentik annak jelentőségét, hogy a családi és az intézményes nevelés problematikus oldalait a szükségletek komplexitása alapján elemezzük.

Maslow gondolatmenetét ismerve (Maslow és Lowery, 1998) a hétköznapi tanulási helyzetekben nem elégedhetünk meg a nehezen kezelhető gyermek viselkedésének egyszerü címkézésével, hogy óra alatt rendbontó, figyelmetlen, tehát fegyelmezést igényel, amikor nem vonódik be a sztenderd iskolai feladatokba. Az iskolai feladatok föként az intellektuális és - megfelelő kihívás esetén - az önaktualizációs 
szükséglethez illeszkednek, de az iskolába érkező gyermek/fiatal teljes személyiségére reflektáló pedagógusok nyitottak lehetnek a rejtettebb jelzések észrevételére is. A családi kontextusban keletkező gyermekbántalmazás (brutális verés, elhanyagolás az egészség gondozása és az étkeztetés terén, a mozgásigény korlátozása) a fiziológiai szükségletek kielégülését akadályozza (Harris et al., 2008), s egyben sérti a gyermeki jogokat. Az óvodában, iskolában ezeknek a gyerekeknek arra van szükségük elsősorban, hogy éhségük csillapításáról, mozgásigényük kielégítéséről fokozott gondoskodás valósuljon meg. Minden gyermek számára fontos, hogy az iskola jól tervezett padokkal, megfelelő világítással ellátott osztálytermekkel és rugalmas időszervezéssel támogassa a fiziológiai szükségletek kielégítését, miközben a bántalmazás miatt elszenvedett stressz feldolgozásához ezek a gyerekek speciális érzelmi gondoskodást is igényelnek. A bántalmazáson túl a biztonságélmény megélésében okoz zavart a három éves kor alatti kórházba kerülés, a gyerek bármilyen életkorában bekövetkezö válás a családban (Ormrod, 2000), iskolai környezetben pedig a gyakori pedagógusváltás és a kortárstól érkező zaklató (bully) viselkedés. Ennek ellensúlyozására képes intézményi környezetben a pedagógus, ha észleli a társas konfliktusok jelzéseit, vagy a gyermek érzelmi ragaszkodásának és stabilitás igényének forrását.

A szeretet és elfogadás szükségletének beteljesülése sérül, ha érzelmi elhanyagolás jelenik meg a szülő magatartásában, ennek ellentéteként a szülő olyan erőteljesen kötődhet gyerekéhez, amivel akadályozhatja, hogy a gyerek a kortársaival barátkozzon és átélje a kortársak elfogadását. Az intézményes nevelésben a társas izolációnak számtalan más oka lehet, amely csökkenthetö, ha a nevelő az egyes gyerek felé irányuló figyelmén, gondoskodásán túl elősegíti a kortársakkal kialakítandó kapcsolatok gyarapodását, melynek része, hogy elfogadó attitüdöt tanúsít a kooperatív tanulási technikák iránt.

A szeretet és elfogadás szükségletének kibontakozását segíti elő a diákok iskolához kapcsolódásának (school engagement) a támogatása (Stith et al., 2003). Az iskolához kapcsolódás viselkedéses komponensét a kutatók úgy határozzák meg, mint rendszeres részvételt az iskolai tevékenységekben, az érzelmi komponenst pedig az iskolával történő azonosulással hozzák összefüggésbe. Gyakran e fogalom szinonimájaként alkalmazzák az iskolához tartozás érzését (school belongingness), amely már elnevezésében is egyértelmüen a Maslow-féle szükségleti kategóriára utal (Jimerson et al., 2003). Az iskola és az osztály társas közege, a kortárskapcsolatok nem egyszerúen jó közérzetet teremtenek, hanem befolyást gyakorolnak a diákok iskolai teljesítményére is. A kutatások eredményei arról tanúskodnak, hogy a jó kortárskapcsolatok akkor járulnak hozzá a hatékony tanulmányi célkitüzéshez és teljesítményhez, ha egyszerre több feltétel is megvalósul (Wentzel, 2005): 1. A kortársak egyértelmüen és nyíltan megfogalmazzák elvárásaikat a tanulási célokkal kapcsolatban, és lépéseket tesznek e célok elérésére, ezáltal kifejezve azt, hogy a tanulmányi teljesítmény a kortárscsoportban értéket képvisel (ezzel a magatartással 
helyezkedik szembe a serdülő szubkultúra normarendszere, melyben az iskolai teljesítmény nem képvisel értéket) (Coleman, 1976). 2. Az osztálytársak készek arra, hogy aktívan segítséget nyújtsanak a célok elérésében. 3. A kortárskapcsolatok biztonságosak és nyitottak. 4. A kortársak érzelmi támaszt is nyújtanak, a csoport tagjai érzékelik, hogy társaik elfogadják őket. Az iskolához kapcsolódással rokonítható fogalom az iskolához kötődés (school bonding). Az iskolához kötődés védőfaktorként müködik ott, ahol egyébként a lemorzsolódás veszélyével vagy a fiatalkorú bünözés előjeleivel kell a nevelőknek szembe kerülniük az intézményes nevelés során (Chung et al., 2002; Murray és Greenberg, 2001). Olyan tényezők tartoznak e fogalomhoz, mint a tanárok iránti érzelmi ragaszkodás, az iskolai közösségi és teljesítménycélok iránti elköteleződés. Az iskolához kötődés nemcsak olyan jellemzővel rendelkezik, miszerint a diákok elfogadó attitüdöt tanúsítanak a tanárok iránt, hanem pozitív érzelmi viszonyt táplálnak az osztály, valamint a teljes iskolai élet, az iskolában tartózkodás és az iskolai programok iránt is. A kutatások kiemelnek több olyan tényezőt, amelyek az iskolához kapcsolódás kialakításában fontosnak látszanak és a pedagógusok közremüködése révén valósulnak meg: Ilyen például a tanárok által kezdeményezett kapcsolatépítés, a kölcsönös bizalom kialakítása és nyitott kommunikáció arról, milyen módon kíván segíteni a pedagógus a diáknak abban, hogy az iskolában hosszú távon sikeres legyen. Lényegesnek tünik a rendszeres nyomonkövetés, melynek során a pedagógus arra figyel, vannak-e jelek, amelyek az iskolától való távolodásra utalnak (például hiányzások, nem megfelelö osztályzatok, problematikus viselkedés), amelyek azonban preventív beavatkozással megváltoztathatóak (Sinclair et al., 2003).

A Maslow által leírt önbecsülés folyamatosan sérül a családban, ha a gyereket valamelyik testvérével, rokonával, barátjával hátrányosan hasonlítják össze, vagy nehezen változtatható tulajdonságai miatt elégedetlenséget nyilvánítanak ki rendszeresen. Az iskolában a címkézés, a bünbakképzés, a csúfolás hasonlóan érinti az önértékelést, továbbá az alacsony fokozatú érdemjegyek is hatást gyakorolnak rá, még akkor is, ha igazságos az osztályozás. Ilyenkor a negatív iskolai értékelésre adott válaszként a diákok a tanárt, a tantárgyat, az iskolát leértékelő attitüdöt alakíthatnak ki. Az értékelö-visszajelző folyamatban a formatív értékelés előtérbe helyezésével támogathatják a nevelési intézmények e szükséglet kielégítését (Eggen és Kauchak, 2001). Az önaktualizáció szükségletének kibontakozását akadályozza, ha a szülő nem keresi a gyermeke erős oldalait és nem támogatja ilyen irányú szabadidős tevékenységét, magasabb életkorban pedig nem támogatja a serdülő személyére szóló pályaválasztás megvalósulását. Ugyanennek a szükségletnek az érvényre jutását akadályozza az iskola, ha nincs tekintettel az egyéni szükségletekre, ha nem foglalkozik a lemaradók felzárkóztató oktatásával, a tehetségek speciális fejlesztésével, ha nem tartja feladatának a differenciált oktatást. Az iskola akkor támogathatja ezen szükséglet kielégülését, ha az adott gyermek számára kihívást jelentő feladatokat biztosít, és olyan oktatási környezetet teremt, amelyben több feladattal 
történő tanulás lehetséges ugyanazon órán, a felvetett problémák megoldása nemcsak konvergens, hanem divergens gondolkodási müveletek alkalmazására is lehetöséget ad (Ormrod, 2000).

\section{Környezeti kontroll, jutalmazás és büntetés}

Amíg a Maslow-elmélet az egyén intrapszichikus motivációs szerkezetének egy alternatíváját jelenítette meg, addig a viselkedéslélektan az egyénre általában kényszerítő módon hatást gyakorló környezeti tényezőkkel foglalkozik. A viselkedéslélektan álláspontja szerint, amíg meg nem szilárdult egy új viselkedés, addig közvetlenül fontos annak a jutalmazása, ha azonban azt kívánja pedagógus, hogy az elsajátított viselkedést kitartóan alkalmazza a diák, akkor ritkábban kell kapnia a jutalmat (Johnson, 1979). A ritka, elégtelen jutalomnak nem csak az a következménye, hogy jutalom nélkül is végrehajtja a diák a cselekvést (kevesebb dicséret után is többet tanul a gyerek). A kognitív-behaviorista disszonancia elmélet alapján azt mondhatjuk, léteznek olyan helyzetek, amelyek esetén az egyén szívesen végzi azt a tevékenységet, amiért kevés jutalmat kapott (Festinger, 1972). Önbecsülését bizonyos határig azáltal tartja fenn, hogy megkedveli azt a tevékenységet, amelybe sok erőfeszítést fektetett. A magas tanulási motivációval rendelkező jó tanuló tartja fenn így önbecsülését akkor is, ha nem mindig ér el sikert és nem mindig kap elismerést tanárától. Ez a kognitív-behaviorista álláspont arra mutat rá, hogy a jutalmazás és büntetés a diák egyéni jelentésadási, értelmezési folyamatainak függvényében lehet hatékony vagy célt tévesztő. A jutalmazás egy gyakori formájának, a hatékony dicséretnek a jellemzőit a következökben lehetne összegezni (Brophy, 1981): - következetesen adják, - spontán, változatos és őszinte, - információt nyújt a tanuló teljesítményének értékéről, - a tanuló saját korábbi teljesítményét használja fel a jelenlegi teljesítmény viszonyítási alapjaként, - a tanuló sikerét egyszerre tulajdonítja az erőfeszítésnek és a képességének. A dicséret hatékonysága gyakran azért kétséges, mert rutinszerü, szervezéstechnikai jellegü, vagy a kapcsolat manipulatív befolyásolását szolgálja, emiatt önelfogadtatást, behódolást, őszintétlenséget eredményez, míg a hozzáértően alkalmazott dicséret a tanár és a tanuló személyének tiszteletéhez járul hozzá. Különösen a serdülökorú diákoknál kell olyan paradox jelentésadási folyamatokkal számolnia a pedagógusnak, amelynek következtében szándékaival ellentétes hatást érhet el, ha nem elég körültekintő a jutalmazás megvalósításában. A nem megfelelően alkalmazott dicséret egyes esetekben büntetés is lehet, mint ahogy a diák számára értéktelennek minősülő jutalomtárgy, illetve a rosszul megválasztott tevékenységjutalom végül is büntetésként hat (Brophy, 1983). A jó képességü, megfelelő önállósággal rendelkező serdülőnek adott dicséret azt sugallja számára, hogy azért kell őt folyton dicsérni, mert nem eléggé értelmes. Az önálló feladatvégzés igényével rendelkező diák számára elismerés lehet a kritika, mert úgy véli, a tanár a kritikával azt fejezi ki, elég jó képes- 
ségünek tartja ahhoz, hogy a kritika nyomán képességeinek megfelelően fejlődjön (Brophy, 1978).

A büntetéssel szemben a pszichológia különféle irányzatai általában fenntartásokkal élnek, és azt sugallják, hogy a büntetést negatív hatásai miatt ne alkalmazzák pedagógiai eszközként. Ez az összefüggés igaz a gyermekbántalmazásnak minősülő és ilyen súlyossági fokú esetekre, de nem érvényes a viselkedéskontrollt előtérbe helyező szabályozási módokra. A viselkedéslélektan is felhívja a figyelmet a súlyos büntetés ártalmaira és bejósolhatatlan következményeire, de nélkülözhetetlennek tekinti a büntetést a viselkedés szabályozásában. A büntetés révén kialakuló negatív élmény figyelmezteti a gyereket arra, hogy viselkedése helytelen. Büntetés nélkül az erőteljesen agresszív gyerek jutalmazásnak éli meg azokat a helyzeteket, amelyekben gyengébb, félénkebb társai fölött győzelmet arat. Félreértés lenne azonban azt hinni, hogy a büntetések hatására a gyerek viselkedése minden esetben a kívánt irányban fog változni. A büntetés behódolás jellegü kapcsolatot hoz létre a nevelő és nevelt között (Kelman, 1972; Tedeschi és Lindskold, 1976). Ennek egyik következménye, hogy kerülőutakat választ a gyerek a tiltott tevékenység végzésére. Ez az a magatartásforma, amit a nevelö őszintétlennek minősít. Az őszintétlenség, mint védekező attitüd a büntetés egyik kockázatos következménye, mert a gyerek addig viselkedik jól, amíg látható, amíg ellenőrzés alatt áll, majd amikor a felügyelet megszünik, tiltott viselkedéssel él. A büntetés cinizmust és lázadást is eredményezhet, mely iskolai környezetben 11-12 éves kortól válik egyre gyakoribbá. Kialakulása a kognitív disszonancia alapján magyarázható. Amikor egy diák rendszeresen előforduló szabályszegő viselkedéséért egyre súlyosabb büntetést kap, akkor a pedagógus azzal az elöfeltevéssel él, hogy a diáknak fontos a szabálykövető viselkedés fenntartása és a pedagógussal kialakítandó jó kapcsolat. Ezzel szemben az erőteljes büntetések hatására a diák úgy látja, úgysem tudja elérni a célt, önértékelésének védelme érdekében tehát leértékeli a szabálykövető viselkedést, egyúttal a büntetés jelentőségét és a tanárral fenntartott kapcsolat fontosságát. A büntetés alkalmazásánál fellépő ellentmondások egyike, hogy a rossz időpontban adott, erős intenzitású büntetés jutalomnak számít egy serdülő diák számára, ha olyan alcsoport sztárja, melynek normái szemben állnak az iskola intézményes normáival. A nyilvános, erős intenzitású büntetés rokonszenvet, együttérzést ébreszt iránta a kortársakban. Amikor a büntetést a modellkövetésre tekintettel alkalmazzuk, akkor különösen figyelnünk kell a büntetési helyzet többértelmüségének a kezelésére (Anderson és Bushman, 2002).

Általánosan elmondható, hogy a modellkövetés hatásait figyelembe vevő büntetés a csoport integritását, a csoportnormák sebezhetetlenségét és a normákat betartató tekintélyszemélyek védelmét szolgálja, mert a normákban és a tekintélyszemélyek magatartásában érték testesül meg. Azonban közvetlenül nincs hatással a büntetett egyén véleményének vagy viselkedésének változására, - különösen serdülőkorban -, ha a diák a szervezeti normákkal ellentétes értékeket vall fontosnak 
önmaga számára. Figyelmezteti azonban a diákot arra, hogy egy csoporthoz tartozva felelösség terheli abban, milyen normákat hágott át, milyen értékeket sértett meg. A kockázatot jelentő negatív következmények a büntetés esetén úgy csökkenthetők, ha a helytelen viselkedés előfordulásakor a történéshez közeli időpontban kap büntetést a fiatal gyerek, de egyúttal jutalomban is részesül a helyes viselkedéséért (Woolfolk, 2001). A büntetés akkor hatásos, ha a gyerek nevelőjéhez érzelmileg ragaszkodik és szeretné helyreállítani a büntetés miatt megromlott érzelmi viszonyt. A szeretetkapcsolaton nyugvó enyhe büntetés büntudatot alakít ki, mely a viselkedés belső szabályozójává válik, míg a szeretetkapcsolat hiányával párosuló nevelés büntudat nélküli szégyent kelt. Ez az összefüggés különösen kritikussá válik a pedagógus-diák kapcsolatban abból a szempontból, hogy a pedagógus mennyire tartja fontosnak a referens hatalom készségeinek a kialakítását. Minél fiatalabb a gyerek, annál nagyobb a nevelő felelőssége abban, hogy elfogadásra épül-e a kapcsolatuk (Cole és Cole, 1997). A jutalmazás és büntetés hatékony alkalmazása hozzájárul ahhoz, hogy a diák - Ryan és Deci (2000) modellje alapján a kötelesség és szabályelfogadás magasabb szintjére, a bevetített szabályozás szintjére lépjen, míg a hibákat tartalmazó eljárások a motiváció hiányát tartják fenn, vagy ellenállást eredményeznek a kívánt cél elérése tekintetében.

\section{Öndetermináció, extrinzik és intrinzik motiváció}

A motiváció öndeterminációs elmélete szerint alapvető kérdés, hogy azért kezdeményez egy viselkedést a személy, mert érdekei és értékei ezt diktálják, vagy azért, mert valamilyen külső kényszerítés - például jutalmazás vagy büntetés - alatt áll (Ryan és Deci, 2000). Az ilyen kérdésfelvetés különféle eltérö kulturális környezetben is jelentéssel bír, s egyben olyan dimenziót képez, amely mentén a személyek saját és mások viselkedéseit értelmezik. Ha összehasonlítjuk olyan egyének cselekvéseit, akik belülről vezérelt motivációval rendelkeznek, olyan emberek viselkedésével, akik külsőleg irányítottan cselekszenek, azt tapasztalhatjuk, hogy az előbbiek sokkal több érdeklődést, magabiztosságot, megnövekedett teljesítményt, kitartást és kreativitást tanúsítanak, mint az utóbbiak (Anderson et al., 1976; Deci és Ryan, 1985). Az öndeterminációs felfogásban az önmotiváció és a személyiség integrációjának alapját képező belső növekedési tendenciák, valamint a veleszületett pszichológiai szükségletek képezik a vizsgálódás tárgyát, továbbá azok a feltételek, amelyek e pozitív folyamatokat segítik elő. Empirikus munkára alapozva a szerzők három ilyen belső szükségletet azonosítottak, amelyek a természetes növekedés és integráció optimális működését támogatják: a kompetencia, a társas kapcsolódás és az autonómia szükségletet. Az öndeterminációs elmélet azonban nemcsak az egyénre jellemző pozitív fejlődési tendenciák specifikus természetével foglalkozik, hanem azokat a társas környezeteket is vizsgálja, amelyek ezeket hátráltatják. 
Az intrinzik motiváció koncepciója úgy jellemzi az emberi természetet, mint amelyben biológiailag kódolt információk formájában van jelen a hajlam a spontán érdeklődésre, a Piaget által leírt asszimilációra, a mesteri fokú (mastery) tanulásra és a felfedezésre. Az intrinzik motivációs megközelítés magába foglalja Harter effektancia-elméletét (Harter, 1992; Józsa, 2002). Harter mesteri motivációs, vagy effektancia-modellje értelmében, egy feladathelyzetben végzett sikeres cselekvések, mint mesteri kísérletek, pozitív megerősítést jelentenek az egyén számára, és az így átélt jutalomélmények internalizálásához vezetnek. Ezek a tapasztalatok növelik a kompetencia és az újabb cselekvések feletti belső kontroll érzését, ami növeli az egyén pozitív élményeit, és ezáltal tovább növeli a mesteri motivációt. Ezzel szemben, amikor a mesteri teljesítményre törekvés kudarchoz vezet, akkor a mások általi elismerés vagy jóváhagyás szükséglete marad fenn, az ezzel együtt járó külső kontroll hiedelemmel együtt, amely csökkenti a kompetencia hiedelmeket, és magasabb szorongáshoz vezet, ezáltal csökkenti a mesteri motivációt. A modell azért fontos, mert összekapcsolja a kompetencia hiedelmeket a belső motivációval és megerősíti az optimális kihívást jelentő feladatok összefüggését a kompetencia hiedelmekkel.

A kompetencia érzése azonban önmagában véve nem növeli az intrinzik motivációt, ha azt nem kíséri az autonómia érzése, vagy attribúciós fogalmakkal élve, ha az okság helyét nem belsőnek tételezi a személy (deCharms, 1968). Tehát ahhoz, hogy az egyén intrinzik módon motivált legyen, nemcsak a kompetencia és a hatékonyság érzésére van szükség, hanem azt is át kell élnie, hogy autonóm módon cselekszik. A környezeti események hatásait vizsgáló kutatások nagy része nemcsak a kompetenciával, hanem az autonómia kérdésével is foglalkozott. Heves vitákat váltott ki annak ismételt bizonyítása, hogy a külső jutalmak aláássák az intrinzik motivációt. Ez az összefüggés nemcsak a kézzelfogható jutalmak esetén érvényesül, hanem a fenyegetésekre, határidőkre, útmutatásokra, nyomasztó értékelö helyzetekre és kikényszerített célokra is igaz (Deci et al., 1999; Németh, 1999). Ezzel szemben a választási lehetőség, az érzelmek elfogadása és az önirányítás, lehetővé teszi a nagyobb autonómia átélését, növeli a belső motivációt is. Jóllehet az autonómia és a kompetencia érzése a belső motiváltság változékonyságát csaknem kimerítően megmagyarázza, egy harmadik tényezőt is figyelembe kell venni, az érzelmi kapcsolódást, a kötődést. A kötődéselmélet értelmében végzett kutatások kimutatták (például Bowlby, 1979), hogy a biztosan kötődő csecsemők, akiknek anyjuk támogatja az autonómia szükségleteiket, sokkal több explorációs, kereső-kutató viselkedést tanúsítanak. Az öndeterminációs elmélet azt feltételezi, hogy hasonló dinamika fordul elö életünk során társas környezetünkkel, ezért nem mellőzhető az intrinzik motiváció fenntartása szempontjából, hogy a diákok közömbös, ellenséges vagy éppen támogató attitűddel rendelkező pedagógus jelenlétében végzik tanulási tevékenységüket, s hogy a tanulmányi munkájukra vonatkozó ellenőrzés, értékelés, visszajelzés milyen társas környezetben valósul meg. Ezen kívül fontos még azt a szempontot is figyelembe venni, hogy az emberek nemcsak 
olyan esetekben lesznek intrinzik módon motiváltak, ha a cselekvés önmagában véve jutalmazó a számukra, hanem akkor is, amikor ezt a környezeti feltételek lehetővé teszik, például, ha a cselekvés vagy a feladat újszerü, kihívást jelent, vagy esztétikai értéke van.

Az öndeterminációs elmélet egyik legfontosabb eleme, melynek jelentős hatása van a jelenkori motivációs felfogásra, hogy foglalkozik azokkal a folyamatokkal, amelyek révén önállóvá válnak a kezdetben belsőleg nem motivált viselkedések, és azokkal a módokkal is, amelyekkel a társas környezet befolyásolja ezeket a folyamatokat. Az extrinzik motiváció olyan cselekvés végrehajtására vonatkozik, melynek célja a cselekvéstől különálló következmény elérése, szemben az intrinzik motivációval, melyet a személy a cselekvésben rejlő megelégedés miatt végez. Az öndeterminációs elmélet azt állítja, hogy az extrinzik motivációval végzett tevékenységek nagymértékben különbözhetnek az autonómia élményének megélése tekintetében. Azok a tanulók, akik azért írják meg házi feladataikat, mert felfogják azok értékét jövőbeni választott karrierjük szempontjából, ugyanúgy külsőleg motiváltak, mint azon diákok, akik szüleik elvárásainak kívánnak megfelelni a házi feladat megírásával. Mindkét példában a házi feladat megírása sokkal inkább extrinzik motívumokra, mintsem az önmagában vett munkaörömre vezethető viszsza. Azonban az első esetben az extrinzik motiváció személyes elfogadással és a választás lehetőségének élményével társul, miközben a második esetben a cselekvés végrehajtása a külső szabályozásnak történő behódolást jelent. Mindkét esetben szándékos viselkedésről van szó, de a cselekvések relatív autonómiája különböző.

Az öndeterminációs elméleten belül létrejött integrációs elmélet magyarázatot nyújt arra, hogyan különböztethetők meg az extrinzik motiváció különböző típusai és azok a kontextuális tényezők, amelyek támogatják, vagy akadályozzák a viselkedésszabályozás belsővé válását és összehangolódását (lásd 1. táblázat).

Motiváció nélküli állapotban hiányzik a cselekvés szándéka. Ez akkor jön létre, ha a diák számára nem értékes a tevékenység, vagy ha nem érezi kompetensnek magát, illetve úgy érezi, hogy a cselekvés nem fogja meghozni a kívánt eredményt.

A külsö, extrinzik motiváció olyan körülmények között lép fel, melynek során a diák a tanulási tevékenységet külső követelmények, vagy jutalomra épülö feltételrendszer elnyerése érdekében végzi. Ilyenkor a tanuló kívülröl irányítottnak, szabályozottnak tekinti önmagát. A szabályozásnak ez a formája megfelel a behaviorizmus operáns kondicionálásának, melynek iskolai környezetre vonatkozó empirikus eredményeit korábban már érintettem.

A bevetitett szabályozás az extrinzik motiváció belsővé válásának első lépése. Ilyenkor a diák elfogadja a szabályozást, de nem teljesen sajátjaként éli meg. Azért viselkedik a kívánt módon, hogy elkerülje a büntudatot vagy szorongást, vagy éppen énjével kapcsolatosan pozitív élményt éljen meg, mint például a büszkeség. Ilyenkor a diák viselkedése nem annyira a külső jutalmaktól és büntetésektől függ, mint inkább az önértékelésétől. Ennek a klasszikus formája az énbevonódás. Ilyen 
helyzetekben a diákok azért motiváltak a teljesítésre vagy a kudarc elkerülésére, hogy fenntarthassák az értékesség érzését. Noha belülről irányított viselkedésekről van szó, az egyén az okságot mégsem helyezi belülre. Az azonosulás révén történö szabályozás már inkább jellemezhető intrinzik motivációként, mint extrinzikként, és ennek megfelelően inkább jellemzi az öndetermináció. Azonosulást tükröz, hogy a tevékenység célja tudatosan is értéket képvisel a személy számára.

1. táblázat: A viselkedésszabályozás belsővé válásának folyamata Ryan és Deci (2000) nyomán

\begin{tabular}{|l|l|l|}
\hline \multicolumn{1}{|c|}{ Motiváció } & \multicolumn{1}{|c|}{ Okság helye } & \multicolumn{1}{c|}{ Szabályozás } \\
\hline nincs motiváció & személytelen & $\begin{array}{l}\text { nem szándékos } \\
\text { nem értékelö } \\
\text { inkompetencia } \\
\text { szabályozás hiánya }\end{array}$ \\
\hline extrinzik (külső motiváció) & külső & $\begin{array}{l}\text { együttmüködés } \\
\text { külső jutalmak és büntetések }\end{array}$ \\
\hline bevetített szabályozás & valamelyest külső & $\begin{array}{l}\text { önkontroll } \\
\text { énbevonódás } \\
\text { belső jutalmak és büntetések }\end{array}$ \\
\hline $\begin{array}{l}\text { azonosulás alapján történő } \\
\text { szabályozás }\end{array}$ & inkább belső & $\begin{array}{l}\text { személyes fontosság } \\
\text { tudatos értékek }\end{array}$ \\
\hline integrált szabályozás & belső & $\begin{array}{l}\text { kongruencia } \\
\text { tudatosság } \\
\text { szintézis önmagával }\end{array}$ \\
\hline intrinzik & $\begin{array}{l}\text { érdeklödés } \\
\text { öröm } \\
\text { belső megelégedés }\end{array}$ \\
\hline
\end{tabular}

A bevetített szabályozást a pedagógus annak függvényében segítheti elö, hogy milyen mértékben tud bánni referens hatalmával, személyes vonzerejével (Stronge, 2002; Bábosik, 2004; Szitó és Katona, 2004). A személyes vonzerő modellkövetési, azonosulási folyamatokat indít el. A diák olyan szeretne lenni, mint a tanár, mert érzi, hogy a tanár személyes problémáival együtt megérti őt. A kutatások a referens hatalom gyakorlásában hatékony tanároknál több olyan attitüdöt és készséget tártak fel, amelyek a tanárképzés során és a pedagógiai tapasztalatok révén megszerezhetők és alakíthatók. Az a pedagógus, aki személyes vonzereje révén képes hatást gyakorolni tanítványaira, saját viselkedése, érzései és gondolatai tekintetében megfelelő önismerettel rendelkezik. Gondoskodó attitűd jellemzi, meghallgatási készségekkel fordul diákjai felé, amikor problémákkal érkeznek hozzá. Ismeri tanítvá- 
nyait, ennek segítségével a tanulási folyamatot elősegítő kapcsolatokat hoz létre. Tudja, hogy létezik az iskolán kívül olyan tanulói kultúra, mely gyakran eltér az iskola világától. Az igazságosság és tisztelet fenntartására törekszik. Ezt úgy éri el, hogy a rendbontásra egyéni szinten és nem csupán az egész osztály elött reagál, ha a körülmények ezt lehetővé teszik. A diákokkal való kapcsolatfelvételében túllépi az osztályterem kereteit. Részt vesz olyan sporteseményeken, koncerteken, amit a diákjai lényegesnek tartanak. Többféle helyzetben ismeri meg a diákjait, ezáltal sikeresebben ad kihívást jelentő feladatokat számukra. Lelkesedéssel tanít. Szervezett osztálytermi környezetet alakít ki. Nem egységes rutint követ, hanem differenciáltan motivál. Nem-versengő tanulási stratégiák alkalmazásával alakít ki érdekes tanulási környezetet. A lelkesedés nemcsak azáltal nyilvánul meg, hogy a tanításhoz kapcsolódik, hanem nyitottságot jelent az élet iránt. Ha a diákok megkérdezik a tanárt életfelfogásáról, képes azokról az értékekről beszélni, amelyeket fontosnak tart saját életének alakításában. Felelősséget vállal a tanítás eredményességéért. Elvállalja a felelősséget a tanuló sikerének létrehozásáért. Úgy véli, rajta múlik, hogy többféle módon közelítsen a diákjaihoz, megtapasztalva, milyen módszer válik be. Reflektív gyakorlat jellemzi.

A beépülő extrinzik motiváció leginkább autonóm formája az integrált szabályozás. Akkor beszélhetünk integrált szabályozásról, amikor az azonosulással elsajátított szabályokat teljesen beépíti énjébe az egyén, és végül saját énje részének tekinti. A személy úgy észleli, hogy amit csinál, az összhangban áll másfajta szükségleteivel. Az ilyen cselekvések számos jellemzője hasonlít az intrinzik állapotra, mégis extrinzik eredetünek kell tekintenünk, mert a cselekvést valamilyen jól körülírható eredmény érdekében végzi az egyén és nem belső öröm miatt. A szabályozás utóbbi három formáját együttesen az autonóm motiváció fogalmával írják le (Ryan és Deci, 2000). A szabályok internalizálása szakaszokban megy végbe, de nem jelenti azt, hogy a fejlődési állomások kontinuumot képeznének, hanem a már megélt tapasztalatok függvényében valósul meg az internalizálás. A folyamatban meghatározó a kognitív képességek fejlődése és az énfejlődés, aminek az előre haladásával egyre nagyobb mérvü internalizálásra képesek a személyek. A szabályozás típusait és az iskolai teljesítményt vizsgálva Ryan és Conell (1989) azt találták, hogy minél inkább külsőleg szabályozott volt a gyerek, annál kevésbé mutatott érdeklődést és tanúsított felelősséget saját tanulásáért (kevesebb erőfeszítést tett, a kudarcokért inkább a tanárt hibáztatta). Ezzel szemben a bevetített szabályozással jellemezhető tanulók nagyobb erőfeszítéseket tettek, de gyakrabban szorongtak és rosszul tudták kezelni a kudarcokat. Az azonosulással létrejött szabályozással jellemezhető tanulóknál a feladatok iránti érdeklődés volt hangsúlyos, gyakrabban számoltak be arról, számukra öröm az iskola, hatékonyabb megküzdési stratégiákkal rendelkeztek és nagyobb erőfeszítéseket tettek a tanulási célok elérése érdekében.

Az integrált szabályozás elősegítésének egyik kulcstényezője, hogyan alakul a diák kapcsolata a számára jelentős személyekkel. Egy érzelmileg fontos személy 
nemcsak modellként jelenik meg számára, hanem ő az, aki a kívánt cselekvés értékessége mellett megfelelően tud érvelni is. Minél kiegyensúlyozottabb, biztonságosabb kapcsolata van a diáknak a szüleivel, a tanáraival, a barátaival, és a szülők, valamint a barátok is tanulást támogató normákat képviselnek, annál inkább integrált szabályozás várható a tanulási tevékenységében. Az integrációt meghatározó további tényező, hogy a tanulmányi feladatok elvégzése során mennyire érzi magát kompetensnek az egyén. Ha olyan teljesítményre kényszerítjük a gyereket, amire még nem érett, akkor ez hátráltatja az integrációt. Az autonómia érzése talán a legnagyobb mértékben befolyásolja a diák elköteleződését a tanulási tevékenység iránt. Az egyén akkor tud átélni akarati erőfeszítést, ha választási lehetősége van. Ha az egyén nem élhet a tanulmányi feladatok megoldása során választási lehetőséggel, nem érzi öndetermináltnak cselekvését, nem köteleződik el a cselekvés iránt, mindig csak külső nyomás hatására fogja azt végezni. Az autonómia nélkülözhetetlen ahhoz, hogy belső értékké tudja átalakítani a személy a cselekvést. Fontos tehát a lehetőségekhez mérten a tanulási feladatok között választási lehetőséget biztosítani. Ha egy unalmas feladat értékességére vonatkozóan értelmes magyarázatot kap a személy egy olyan embertől, akivel jó kapcsolata van, miközben választási lehetőséggel is rendelkezik, akkor ez elősegíti a külső cél belsővé válása legmagasabb szintjének kialakulását, az integratív önszabályozást. (Ryan és Deci, 2000). A szabályozó, kontrolláló környezet ezzel szemben csak legfeljebb a bevetítés szintjéig juthat el.

A kutatások során az is nyilvánvalóvá vált, hogy nemcsak a külső szabályozás belsővé válásához, hanem az egyénnel veleszületett és biológiai alapokon nyugvó intrinzik motiváció kibontakozásához is támogató környezetre van szükség. Az öndeterminációs megközelítés részelméleteként fogalmazódott meg a kognitiv kiértékelési elmélet, melynek keretében lehetővé válik az intrinzik motivációt serkentő vagy gátló társas és környezeti tényezők azonosítása. Az elmélet azzal érvel, hogy bizonyos társas környezeti események - visszajelzés, jutalmak, kommunikáció - hozzájárulnak a kompetencia érzésének kialakulásához, ezáltal serkentik az intrinzik motivációt az adott cselekvés vonatkozásában. A diák egy tanulmányi feladat végzésekor a kiértékelő folyamat révén megállapítást tesz arra vonatkozóan, hogy a feladat mennyire tartalmaz számára - mesteri motivációt serkentő - optimális kihívásokat, milyen mértékben kap a feladat jellemzőiből származó és a pedagógustól érkező, hatékonyságérzetet növelő visszajelzéseket, a társas környezettől az önértékelését tisztelettel kezelő értékelő megnyilvánulásokat, amelyek támogatják az intrinzik motivációt (Nagy, 2000).

Az optimális kihívások kihangsúlyozásával e megközelítés összefüggésben áll Csíkszentmihályi flow-elméletével, amely az önfeledten végzett cselekvés zónáját az egyén képességei és önmaga vagy a környezet (szülők, tanárok) által kitüzött célok, kihívások optimális kölcsönhatásának területén jelöli ki (Csikszentmihályi, 2001). Csíkszentmihályi az intrinzik motivált viselkedést a tevékenységet éppen 
végző személy közvetlen szubjektív tapasztalataira alapozva írja le, amelyet flownak nevez. Erre jellemző a) egyfajta teljesség érzés, melynek során az egyén a tevékenységben elmerül vagy egybeolvad azzal, b) megszünik az aggodalomra épülő önmegfigyelés, c) a figyelem egy szűk ingerterületre összpontosul, d) az idóérzékelés felfüggesztődik, e) a saját cselekvések és a környezet feletti teljes kontroll válik uralkodóvá. A flow élménye csak akkor élhető át, amikor az egyén azt érzi, hogy az adott helyzetben a cselekvés lehetőségei összhangban állnak a kihívásnak történő megfelelés képességével. Deci és Ryan öndeterminációs elmélete és Csíkszentmihályi flow-elmélete ugyanannak az éremnek a két oldalát jeleníti meg (Csikszentmihályi és Rathunde, 1993). Míg a flow-elmélete egy cselekvés azonnali közvetlen okaira ad magyarázatot, a flow itt-és-most történő átélése biztosítja, hogy az egyén keresse saját kompetencia élményének növelését, addig az öndetermináció részeként megjelenő kiértékelés elmélet viszont egy adott viselkedés végső céljainak elérését magyarázza meg. A végső cél lehet a hatékony önszabályozó tanulás elsajátítása, hogy ennek révén a diák felnőttként jól meg tudjon küzdeni a szakképzettség megszerzésére vonatkozó kihívásokkal, de itt és most a tanulási tevékenységet akkor végzi belső megelégedéssel, ha az adott tevékenység izgalmas vagy örömteli (Réthy, 2002).

Amikor egy diák a dolgozatára, feleletére osztályzatot kap, akkor az öndeterminációs elmélet szerint a motiváció szabályozottságának a foka a külső, extrinzik szintnek felel meg. Ha a diák százalékos vagy szöveges értékelésben részesül, akkor ez a bevetített, illetve az azonosuláson nyugvó szabályozás feltételeit teremti meg attól függően, hogy szummatív vagy formatív értékelési módot alkalmaz-e a pedagógus és miként él referens hatalmával (Csapó, 1978; Golnhofer,1998). A kompetencia érzését növelő mesteri motivációt elsősorban az optimális feladatadáshoz társuló formatív szöveges értékelés segíti elö (Santrock, 2008).

\section{Attribúciók és énhatékonyság}

Az attribúciós elmélet naív tudósnak tekinti a gyermeket és a felnőttet, aki választ keres arra a kérdésére, hogy képes-e az előtte álló feladatot megoldani. A Heider (1958) munkájából kinövő attribúciós elmélet szerint az a fontos, hogy az emberek hogyan értelmezik és magyarázzák a korábbi teljesítménnyel kapcsolatos különböző kimeneteleket (Weiner, 1979). Weiner (1990) azt hangsúlyozta, az egyén jelenlegi és jövőbeli eredményessége szempontjából elsődleges meghatározó tényező, hogy milyen oki attribúciókat hoz létre saját teljesítményével kapcsolatban. Weiner szerint a korábbi teljesítményre történő reflektálás során különböző okoknak tulajdoníthatjuk az adott teljesítményt. Az okok három dimenzió mentén csoportosíthatók:

a) Az ok helye - Az ok helye lehet külső, környezeti feltételrendszerből adódó, mint például a feladat nehézsége, de lehet belső is, ha az elért tanulmányi teljesítményt a képességeknek tulajdonítjuk. Az ok helyével kap- 
csolatos tulajdonítás elsősorban az önértékeléssel függ össze. Ha a dolgozatra kapott jó osztályzat következében elért sikert a diák belső oknak tulajdonítja, akkor ez, az önbecsülése és büszkesége növekedéséhez vezet, ami növeli a motivációt. Ha viszont kudarcot tulajdonít belső oknak, akkor ez önértékelést és motivációt csökkentő hatású.

b) Stabilitás - Ebben az okcsoportban meghatározó, hogy állandó vagy változékony-e az ok helye. Állandó jellemző például a személyiségvonás, változó a hangulat vagy a betegség-egészség. Ez a dimenzió a jövővel kapcsolatos elvárásokkal függ össze. Ha a tulajdonítás állandó okokra vonatkozik - például kitartás vagy lustaság -, akkor az adott területen bekövetkezö siker/kudarc is állandósul. Ha változó okokra következtet valaki például pillanatnyi jókedv vagy fáradtság -, akkor a jövőkép is változékonyabb és az aktuális kudarcot sem nem tekinti véglegesnek az egyén.

c) Szabályozhatóság, az egyén felelőssége - Az egyén által szabályozható okok közé tartozik a tanulás során kifejtett erőfeszítés. Ezért a tanuló maga is felelös. Ugyanakkor az egyén nem képes szabályozni az iskolai követelményrendszert, nem is érzi magát felelősnek érte. Ez a dimenzió elsősorban a düh, hála, szégyen, büszkeség átéléséhez kapcsolódik, továbbá meghatározó jelentőségű atekintetben, hogy milyen mértékü szívességeket és segítséget kap majd az egyén másoktól. Ha a diák a kudarcért tartja magát felelősnek, akkor szégyent él át, ha pedig a sikerért, akkor büszkeséget. Ha kortársai és tanárai úgy észlelik, hogy nem a külső körülmények, hanem a belső, szabályozható erőfeszítés hiányzik a tanulással kapcsolatos tevékenységéböl, akkor egyáltalán nem vagy kevésbé szívesen nyújtanak segítséget számára.

Aki sikerét képességeinek és erőfeszítéseinek tulajdonítja, pozitív érzelmeket él át és a jövőben is sikereket vár el, mert úgy gondolja, a jövőben is kontrollálni tudja ezeket a kimeneteket. Ezzel szemben azok, akik a kudarcaikat képességhiánynak tulajdonítják, szégyent élnek át és csökkentik jövőbeli elvárásaikat. Úgy gondolják, hogy nem tudják szabályozni a kimeneteket, $\mathrm{s}$ az elvárások csökkentésével a kudarc valószínúségét igyekeznek csökkenteni.

Számos fejlődéslélektani kérdés merül fel az elmélettel kapcsolatban. A kritika éle elsősorban az oktulajdonítás bonyolult jellegében talál támadási pontokat. A gyermek gondolkodásában csak akkor válhat hatótényezővé a siker és kudarc okainak laikus elemzése, ha több előfeltétel teljesül. A gyermeknek meg kell értenie az ok és okozat együttjárását, le kell számítolnia ${ }^{1}$ más lehetséges okokat, meg kell értenie egy esemény egyediségét és mennyire következetesen fordul elö. A másik felvetés az, hogy a gyerekek nem tudnak könnyen különbséget tenni a különböző dimenziók

\footnotetext{
${ }^{1}$ A „leszámítolás” azt jelenti, hogy a személy a kézenfekvő okot elfogadja és a többi lehetséges magyarázatot nem veszi figyelembe, „leszámítolja”.
} 
között, ráadásul az egyes dimenziók megértési szintje is változik az életkor előrehaladtával. Például a kisiskoláskorú gyerekek a képességet és az erőfeszítést, egymást kiegészítő tényezőknek látják, és nem különböztetik meg ezt a két konstruktumot. Csak 11-12 éves korban válnak képessé arra, hogy megértsék a két dimenzió reciprok kompenzáló kapcsolatát, miszerint az alacsonyabb képességü személynek nagyobb erőfeszítést kell tennie, hogy ugyanolyan sikert érjen el, mint a magasabb képességü személynek. Ekkor értik meg, hogy a magasabb erőfeszítés egyben az alacsonyabb képesség jele is lehet. További bonyodalmat jelent, hogy a feladatnehézség fogalma is változik az életkorral. Ez azt is jelenti, hogy Weiner modellje nem könnyen alkalmazható különböző életkorú gyerekekre. Faktoranalitikus kutatások pedig alátámasztották a három dimenziót. A belső attribúciók különböző faktorokat képeztek a teljesítményterületnek megfelelően, míg a külső attribúciók egy faktort képeztek területtől függetlenül. Ezek az eredmények megerősítik azokat a kritikákat, amelyek szkeptikusan szemlélik a „gyermek, mint naiv tudós” metaforáját, amit kiterjedten használ az attribúciós elmélet. Amit azonban nem várhatunk el a gyermektől, elvárhatjuk a pedagógustól. Nem közömbös tehát, hogy a dicséret adása, vagy a formatív és szummatív szöveges értékelés során a pedagógus $(M$. Nádasi, 2004a, b.) milyen attribúciókkal értelmezi a különböző életkorú gyermekek teljesítményét. A Vigotszkij nevéhez köthető legközelebbi fejlődési zóna elvére alapozva az ,állványozással" (scaffolding) a fiatalabb gyerek is érzékelni tudja a teljesítményéhez füzött reagálást. Serdülőknél - a korábbi tapasztalatok függvényében erre a támasznyújtásra nincs feltétlenül szükség a visszajelzéseknél, de az ő esetükben sem elhanyagolható, hogy a szabályozható és önbecsülésüket növelö jellemzöik mentén kapnak-e pedagógusaiktól attribúciós sugalmazást, amikor szövegesen értékelik őket (Woolfolk, 2001; Higgins, 1987).

Bandura szociokognitív elmélete azt feltételezi, hogy a múltbeli teljesítmény és a jövőbeni teljesítmény között az énhatékonysággal kapcsolatos hiedelmek játszanak mediáló szerepet (Bandura, 1986). Az elmélet a személy saját kezdeményezőkészségére és a hatékonyságára vonatkozó észleléseit tekinti központi jelentőségünek a teljesítményszükséglet vagy az igényszint alakításában. Az énhatékonyság többdimenziós fogalom: változhat előjelében, pozitív vagy negatív is lehet, változhat az általánosítottság mértékében, lehet egy helyzetre vagy sok helyzetre igaz, de abban is eltérő lehet, hogy csak egyféle nehézségi szinten (például csak könnyü feladatokban) vagy a nehézségi szintek széles skáláján (a könnyütöl a nehézig sokféle feladatban) érzi az egyén hatékonynak magát. Ugyanúgy ahogy az attribúciós elmélet is, Bandura is a sikerrel kapcsolatos elvárásokat hangsúlyozza. Elméletében kétféle elvárás-hiedelmet különböztet meg: a) A cselekvés eredményével kapcsolatos ún. kimeneti elvárások azt a hiedelmet tartalmazzák, hogy bizonyos viselkedések bizonyos eredményhez vezetnek. Például: „Ha többet gyakorlok, könnyebben írhatom meg a dolgozatot.” b) A hatékonysággal kapcsolatos elvárások körébe tartoznak azok a hiedelmek is, amelyek valószínüsítik, hogy az egyén képes-e a kí- 
vánt eredménynek megfelelően végrehajtani a cselekvéseket. Például: „Elég hatékonyan tudok edzeni ahhoz, hogy megnyerjem a következő sportversenyemet." „Képes vagyok-e arra, hogy az eddigi félóra helyett naponta másfél órát tanuljak.” $\mathrm{Az}$ egyénnek lehetnek pozitív hiedelmei a kimenetellel kapcsolatban (például a gyakorlás, edzés növeli a teljesítményt), ugyanakkor ezzel párhuzamosan élhet az egyénben az a hiedelem, hogy nem képes nap, mint nap végrehajtani a gyakorlást, ez pedig a hatékonysággal kapcsolatos negatív elvárás. Az elmélet értelmében az észlelt énhatékonyság az a tényező, ami központi szerepet játszik a célok kitüzésében, a tevékenységek megválasztásában, az erőfeszítés és kitartás létrejöttében. Az észlelt énhatékonyság mértékét négy tényező együttesen határozza meg: 1. a korábbi teljesítmény (a siker magasabb énhatékonyság érzethez vezet), 2. mások verbális biztatása („Hiszem, hogy meg tudod ezt csinálni!”), 3. a vikariáló tanulás (sikeres kortársak megfigyelése, velük való kapcsolat), 4. saját fiziológiai reakciók (a túl magas izgalmi szint és szorongás csökkenti a személyes hatékonyság érzetét, a közepes vagy alacsony javítja azt). Bandura elismerte az oki attribúciók szerepét, de úgy vélte ezek a viselkedést csak akkor befolyásolják, ha összekapcsolódnak az énhatékonyságra vonatkozó hiedelmekkel. Ugyanúgy, mint az attribúciós elmélet, ez is bírálható a túlzottan racionális és információfeldolgozó-hangsúlyú megközelítése miatt.

\section{Motivációs stílusok}

Több motivációs kutató úgy véli, hogy a sikerre és a kudarcra vonatkozó attribúciók, a képességre vonatkozó hiedelmek, az énhatékonyság és az önértékelés a motivációs stílus koncepciója révén kapcsolható egymáshoz (Covington, 2000; Dweck és Legett, 1988; Pintrich, 2005). Három motivációs stílust különböztetnek meg: a mesteri-orientált (mastery-oriented), a kudarckerülő és a kudarcelfogadó stílust.

A mesteri-orientált motivációs stílussal rendelkező személy értékesnek tartja magát a teljesítményt, és képességeiről úgy gondolkodik, hogy azok javíthatóak. E növekedés elméletet hangsúlyozó implicit hiedelem olyan törekvéseket eredményez, melynek következtében az egyén a tanulási célokra összpontosít, hogy javítsa készségeit és képességeit. Nem fél a kudarctól, mert a kudarc nem fenyegeti kompetencia érzését és önértékelését. Ez lehetővé teszi számára, hogy közepesen nehéz célokat tüzzön ki önmaga számára, kockázatokat vállaljon és konstruktívan küzdjön meg a kudarcokkal. Erős énhatékonyság érzés jellemzi, sikereit általában saját erőfeszítéseinek tulajdonítja, így még inkább vállalja a felelősséget saját tanulásáért. Legjobban versengő helyzetben teljesít, gyorsan tanul és ilyen helyzetekben másokhoz képest nagyobb magabiztossággal és energiával rendelkezik, feszültségszintje magas és várja a konkrét visszajelzéseket, ha azt nem fenyegető módon kapja. Türelmetlenül várja, hogy megtanulja a problémamegoldás „fortélyait”, annak érdekében, hogy sikeres lehessen. 
A kudarckerülő diák hajlamos inkább a képességek entitás nézetét magáénak vallani, így inkább teljesítmény-célokat túz ki maga elé (Stipek és Gralinski, 1996). Hiányzik az erős kompetenciaérzés, és énhatékonyság érzése független saját teljesítményétől. Csak annyira érzi okosnak magát, amennyire a kapott osztályzat ezt lehetővé teszi, tehát nehezen vagy szinte soha nem alakul ki nála a biztos énhatékonyság érzése. Annak érdekében, hogy kompetensnek érezhesse magát, védenie kell énképét a kudarcoktól. Ha korábban általában sikeres volt, akkor úgy kerülheti el könnyüszerrel a kudarcot, hogy kevés kockázatot vállal és ragaszkodik ahhoz, amit már tud. Ha azonban a korábbiakban átélt sikertelenségeket és jó néhány kudarcot, akkor olyan stratégiákat alkalmazhat, mint a halogatás, a minimális erőfeszítés, a nagyon alacsony vagy irreálisan magas célok kitűzése, a „nekem mindegy” attitüd hangoztatása. A kudarckerülő stratégiák önsorsrontó stratégiák, ugyanis éppen a kudarcnak a valószínüségét növelik, amelynek pedig az elkerülésére szeretne törekedni a diák. Ha a kudarcok folytatódnak és a kifogások kimerülnek, akkor a diák arra a következtetésre juthat, hogy inkompetens, az önértékelése és az énhatékonyság érzése csökken, feladja a helyzetet és kudarcelfogadó motivációs stílust alakít ki. Az ilyen diák tovább már nem tudja megvédeni magát attól a következtetéstől, hogy problémái alacsony képességeiből származnak. Az attribúciós elmélet értelmében azok a diákok, akik úgy látják, hogy kudarcaikat alacsony képességeik okozzák és ez a képesség megváltoztathatatlan (entitás nézetet vallanak), nagy valószínüséggel depressziósokká, apatikussá és tehetetlenné válnak.

A tanárok képesek néhány kudarckerülő diákot megóvni attól, hogy kudarcelfogadóakká váljanak, ha segítenek diákjaiknak új és reálisabb célok felállításában, vagyis abban, hogy a mastery stílusú gondolkodásmódhoz közelítsenek. Néhány diáknak támogatásra lehet szüksége atekintetben is, hogy magasabb teljesítmény célokat tüzzenek ki az etnikai vagy nemi sztereotípiák ellenében, illetve arra vonatkozóan, hogy mit „kell” tenniük, vagy mire „,nem kell” képesnek lenniük. Ahelyett, hogy sajnálná vagy felmentené a tanár a diákot, megtaníthatja arra, hogyan tanuljon és miként vállaljon felelősséget saját tanulásáért.

\section{Elvárás-érték elmélet}

A motiváció több elemét integráló elvárás-érték elmélet (Wigfield és Eccles, 2000) szerint a teljesítményszintre vonatkozó elvárások és a tanulási feladat tartalmának értékességét meghatározó nézetek közvetlenül befolyásolják, hogy a tanuló miként választ a tanulmányi feladatok között és mennyire lesz kitartó (1. ábra). A teljesítményszintet és a sikert érintő elvárások gyökerei a családban és a tágabb kulturális miliöben keletkezett nézetekre vezethetők vissza, míg a szubjektív feladat-érték a gyermek képességeinek jellemzői és a teljesítményhez füződő korábbi tapasztalatainak függvényében alakul. A továbbiakban akként formálódik a gyermek motivációs rendszere, hogy ezt az indulásként és háttérként kapott információs bázist miként 
észleli és milyen módon értelmezi, vagyis milyen attribúciókat hoz létre. Az észlelések és attribúciók az énkép szürőjén keresztül hatnak a célkitüzésekre, majd a tanulmányi sikerre vonatkozó elvárásokra, míg a szubjektív feladat-érték tartalma a sikerekhez és kudarcokhoz füződő érzelmi emlékek feldolgozásának hatékonyságával függ össze.

Egy adott feladat szubjektív feladatértékét három motivációs komponens határozza meg. Az egyik a feladat intrinzik értéke: az öröm, amit az egyén átél amiatt, hogy a cselekvést elvégzi, de jelenthet szubjektív érdeklődést is az adott témakör iránt. A másik, a hasznosság-érték, melynek meghatározója, hogy az adott feladat mennyire jól illeszkedik a jelenlegi vagy jövőbeli célokhoz. Egy feladatnak azért lehet pozitív értéke a személy számára, mert támogatja a fontos jövőbeli célokat még akkor is, ha a feladat önmagában véve nem élvezetes. Diákok gyakran tanulnak kitartóan olyan tantárgyakat, amelyeket nem különösebben kedvelnek, de szükségük van az elvégzésükre ahhoz, hogy a jövőben elérjenek valamilyen további célt - a tantárgy emiatt fontos. Az is lehet, hogy csak azért veszik fel, hogy együtt lehessenek barátaikkal, vagy örömet okozzanak szüleiknek. Ilyen értelemben ez a motivációs sajátosság inkább extrinzik jellemzőkkel bír. Egy harmadik elem, a költség, ami nem más, mint a feladat vagy a tevékenység elvégzésének negatív aspektusa. Ilyen például a teljesítményszorongás, a sikertől vagy a kudarctól való félelem, de költség lehet az eröfeszités is, ami a siker eléréséhez szükséges és azok az elveszített lehetőségek is, amelyeket az adott tevékenység választása miatt a tanulónak mellőznie kell.

Az elvárás-érték elmélet által felvázolt motivációs térkép fogalmi rendszerének keretein belül értelmezhető, hogy az iskolai sikerességet miként befolyásolja az etnikai csoport iránti elköteleződés, az ehhez füződő társas identitás kialakulása (Thomas, 2001; Kroger, 2007). Az etnikai csoporthoz tartozás tudata és elmélyítése a mentális egészség része, de ezzel párhuzamosan a társadalom domináns értékrendjével szemben keletkező attitüd és ellenkultúra megnyilvánulásának színtere is (Fisher, 2005). Ha a fiatal nem lát olyan modelleket saját csoportjában, akik a társadalmi hierarchiában magas szintre jutottak, karriert futottak be és ezt a karriert iskolai tanulásukkal alapozták meg, akkor a saját csoportjával történő azonosulása egyben az iskolai teljesítménnyel szembeni ellenállást eredményezi. Úgy érzi, akkor hűséges a saját csoportjához, ha visszafogja teljesítményét az iskolában. Angolszász kutatások ugyanakkor különbségeket is kimutatnak az etnikai csoportok között atekintetben, hogy a gyermekek nevelésében mennyire játszik szerepet a teljesítményre orientálás. A perfekcionizmus vizsgálata során arra az eredményre jutottak, hogy amíg az afro-amerikai fiatalok szüleikről úgy vélekednek, mint akik nem tanúsítottak magas elvárást az iskolai tanulmányaikkal szemben, addig az ázsiai-amerikai fiatalok szüleiket úgy emlegették, mint akik mentálhigiénés problémákat okozó magas teljesítményt vártak gyermekeiktől, tanulásra szorították őket, a pihenés és a játékos szabadidő eltöltés rovására (Nisson et al., 1999; Wei és Mallinckrodt, 2004; Kim, 2006). 


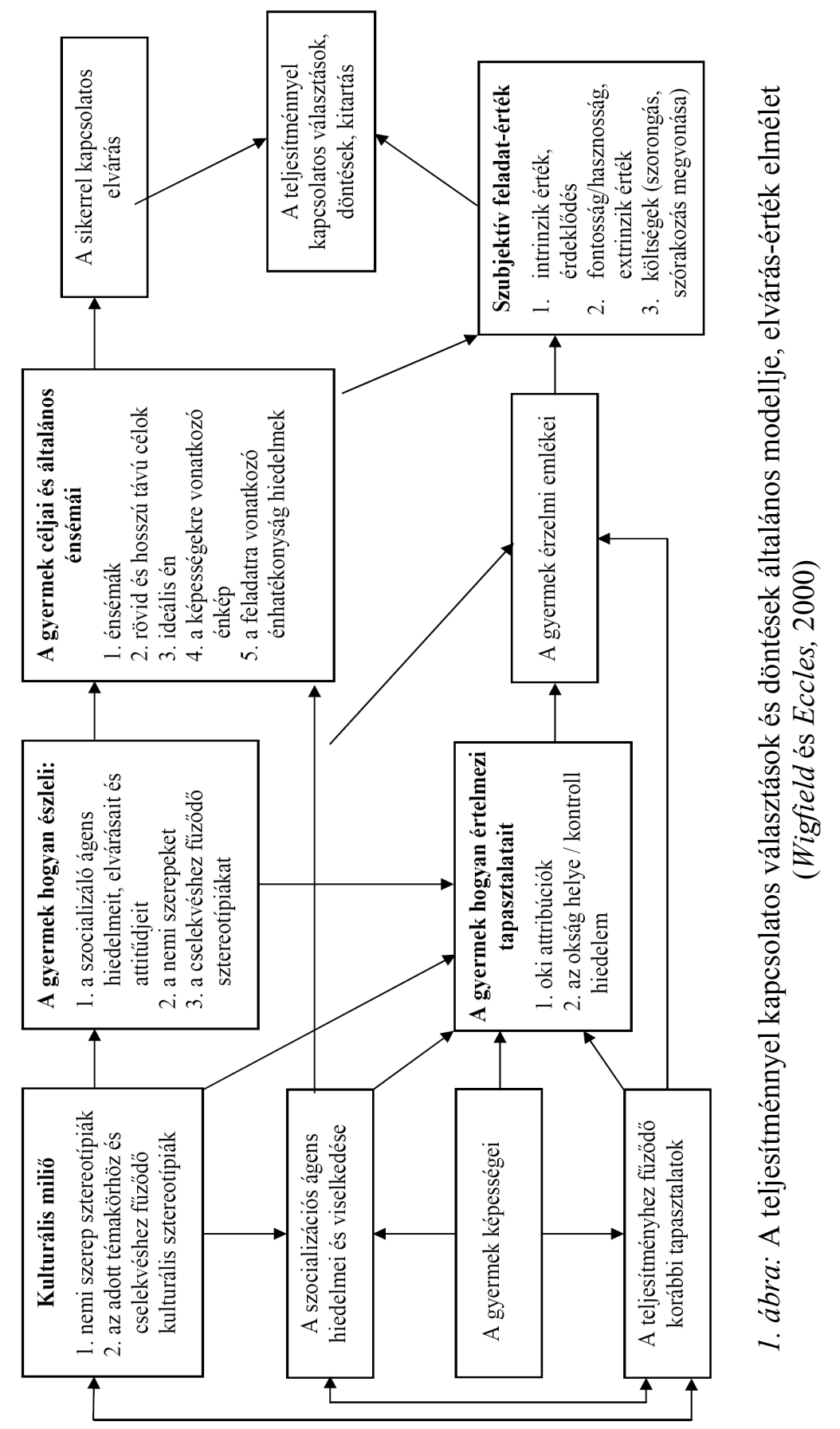


Az etnikai csoportok közötti kulturális különbségek jellemezhetők a kognitív stílus alapján is, mely ugyancsak befolyást gyakorol a gyermekek iskolai teljesítményére. Azokban az országokban, ahol az egyéni különbségek kutatása kiterjedt a kulturális sajátosságok leírására is, azt találták, hogy egy-egy etnikai csoport kognitív stílusa és a teljesítményre vonatkozó hiedelemrendszere eltérhet az iskolában elvárt sikerkritériumoktól, s ennek következményei lesznek az iskolai teljesítésben (Shade, 1982; Vajda és Kósa, 2005). A kulturális különbségekre irányuló kutatások az afroamerikai csoportoknál kimutatták, hogy e csoportokban a társas kapcsolatok képezik az élet alapját, nem a tárgyak, a vagyon vagy a tulajdon birtoklása. A csoport iránti hűség előbbre való, mint az egyéni jogok és kiváltságok rendszere. Iskolai környezetben ennek a közösségre irányuló stílusnak a nem-versengő tanulási motiváció kedvez, a munkaforma tekintetében pedig a kooperatív tanulás (Boykin et al., 2005). Egy további eleme ennek a kognitív stílusnak a mozgásközpontúság és a mozgáson, ritmuson nyugvó kifejezőkészség. A ritmus megnyilvánul a beszéd szerveződésében, a hétköznapi mozdulatokban és a tánc kedvelésében, ezzel együtt igen hangsúlyos az érzelmek kifejezésében is. Egy további jellemző a magas intenzitású ingerkörnyezet elöidézése, fenntartása, mely kifejezésre jut az intenzív érzelmekkel kísért beszédben, a viselkedés szenvedélyes lendületében, a környezeti ingerek változatosságának előnyben részesítésében. A fentiekből következik, a gyerekek olyan iskolai környezetet kedvelnek, amely lehetővé teszi, hogy a tanulás alatt zene szóljon, mozgással legyen egybekötött a tanulás, és adjon lehetőséget az érzelmek kifejezésére. A navajo indiánoknál végzett kutatások arra utalnak, hogy a tanulási hiedelmek, motivációk és preferenciák tekintetében ugyancsak a kapcsolódási, affiliációs motívum, a társ- és csoportorientáció, a kooperatív tanulás emelkedik ki a versengésre és egyénre irányuló tanulással szemben (McInerney és Swisher, 1995).

A nemek közötti motivációs különbségek közül legtöbbet az énhatékonyság hiedelmek és az énkép alakulása terén tárták fel. Az eredmények szerint a lányok nagyobb énhatékonysági hiedelmekkel rendelkeznek, mint a fiúk, olyan területeken, mint az írás és olvasás, a fiúk viszont a matematika, a természettudományok, a sport és az informatika világában birtokolnak magasabb énhatékonysági hiedelmeket, mint a lányok. A fiúk elvárás-érték hiedelmei általában magasabbak a sport és a matematika területén, mint a lányoké, míg a lányoknál ugyanez a jellemző a hangszeres játékra vonatkozóan mutatható ki (Bembenutty, 2008). Etnográfiai vizsgálatok arra utalnak, hogy a nemi identitás és a tanulmányi énkép sajátosságainak összeegyeztetése a lányok számára a serdülőkor kezdetétől igen nehéz. Az interjúkban a diákok beszámoltak arról az ellentétről, ami a lányok tanulmányi sikerével és a nőiességgel kapcsolatos elvárások között jelentkezik, érzelmi feszültséget okozva számukra, mert úgy észlelték, hogy egy lány magas teljesítménye „nem normális". Orenstein azt találta (idézi: Ormrod, 2000), hogy az okos lányok féltek attól, hogy elidegenednek fiú kortársaiktól, akik nem értékelik a lányok intellektuá- 
lis képességeit, és amiatt is aggódtak, hogy lány társaik, barátnőik pedig versenytársnak látják őket tanulmányi téren.

Az elvárás-érték motivációs modell a hátrányos helyzetből fakadó problémákat is bevonja értelmezési körébe (Hallinger és Murphy, 1986; Szitó és Katona, 2007). Ha egy iskolában nagy létszámban vannak jelen hátrányos helyzetủ gyerekek (a gyermeklétszám egyharmadánál többen), ez befolyást gyakorol az iskolakultúra alakítására. Két kutató (Hallinger és Murphy, 1986), hátrányos helyzetüeket befogadó és ugyanennyi magas szociokulturális körülményekkel rendelkező diákokat oktató iskolában végzett vizsgálatokat. A pedagógiai program tartalma, az alkalmazott oktatási eljárások és a szülőkkel való kapcsolat szempontjából olyan intézményeket választottak ki, amelyek a saját referenciacsoportjukon belül sikeresek voltak. Az eredmények azt mutatták, hogy a kedvezőbb helyzetü iskolákban a szülők támogatták gyermekeik továbbtanulását, az elméleti tárgyakat magasra értékelték, a tanárok motivációs stratégiája több intrinzik elemet tartalmazott. A kedvezőtlen helyzetü intézményekben azonban a tanár volt a továbbtanulásra vonatkozó magas elvárás forrása, míg a szülők megkérdőjelezték a továbbtanulás fontosságát. Távol tartották magukat az iskolától, ritkán látogatták, mert az intézmény saját kudarcaikra emlékeztette őket, vagy nem értettek egyet az iskola céljaival. A tanárok motivációs eljárásaik során gyakran alkalmaztak anyagi vagy tevékenységjutalmakat, extrinzik motivációra támaszkodtak.

\section{Az önreguláció és a motiváció szociokognitív elméletei}

Az önszabályozó tanulás modellje olyan cselekvéselmélet, mely egy feladat megtanulására vonatkozó döntés meghozatalát követő tevékenységek lefolyását kívánja megérteni. Olyan kérdésekkel foglalkozik, mint a motiváció átalakulása szabályozott viselkedéssé, vagy a motiváció és a kogníció kapcsolata. A folyamat egyik kulcseleme a tanulás önellenőrzését vezérlö metakogníció, a másik az akarati kontroll jelenléte, mely Kuhl és Corno munkássága révén került a kutatók figyelmének középpontjába, és vált az önszabályozó tanulás modelljének szerves részévé (Corno és Rohrkemper, 1985; Kuhl és Kraska, 1989; Kuhl, 2000). E ponton azonban nem szabad megfeledkeznünk Vigotszkijról, aki már az 1930-as években kidolgozta a magasabb pszichikus funkciók elméletét, s akinek gondolatai csak az 1970-es évektől váltak az angolszász kutatások inspirálóivá. Vigotszkij (1971) szociokognitív modelljében a magasabb pszichikus funkciók múködésmódjából származtatható az akarat (Gray és Feldman, 2004), amelynek kezdetét az általa kialakított rendszerben a Piaget felfogásától eltérően értelmezett egocentrikus beszédben fedezhetjük fel, mely aztán később, mint belső beszéd, a problémamegoldás eszköze lesz. A viselkedéslélektanban viszont mint énre irányuló beszéd (Meichenbaum és Goodman, 1971) az önjutalmazás, tehát a motivációs rendszer önirányításának bázisává válik. A belső beszédre támaszkodó akarati folyamatok és 
az önszabályozó tanulás vonatkozásában $K u h l$ azt kifogásolta (Kuhl, 2000), hogy sok kutató a folyamat akarati elemét figyelmen kívül hagyta, azt feltételezve, hogy a motiváció megléte közvetlenül megfelelő teljesítményhez vezet. Szerinte azonban a motivációs folyamatok csak a cselekvéssel kapcsolatos döntéshez vezetnek el, amikor azonban az egyén megkezdi a cselekvést magát, akkor már akarati folyamatok veszik át az irányítást és határozzák meg, hogy a szándék beteljesül-e vagy sem. A figyelemelterelő ingerek még a legerőteljesebb szándékokat is képesek megingatni, így tehát az akarattal, mint metamotivációs folyamattal külön elemként szükséges foglalkozni.

Az önszabályozó tanulás mai formájának kialakításához több kutató járult hozzá munkásságával. Bandura (1986) szociokognitív elméletében az önszabályozó tanulás úgy jelenik meg, mint amelyben a tanuló saját tanulásának mestereként ellenőrzi a tanulás során kitüzött céljainak és motivációinak helyességét, környezeti erőforrásokat mozgósít a tanulás fenntartása érdekében, döntéseket hoz viselkedésének korrekciója érdekében. Pintrich és munkatársai modelljében az önszabályozó tanulás egy olyan aktív folyamat, amelynek során a tanulók célokat tüznek ki a tanulásukhoz, és megkísérlik ellenőrizni megismerési folyamataikat, motivációjukat és a viselkedésüket (Pintrich és DeGroot, 1990; Walters et al., 2003; Molnár, 2000; Molnár, 2002). Az önszabályozásról a legárnyaltabb fogalmi megközelítést Zimmermann és munkatársai hozzák létre. Szerintük egy konkrét tanulási feladat megoldása során megvalósuló önszabályozás folyamata három szakaszra különíthető el: a tervezés, a teljesítmény és az önreflexió fázisai (Zimmerman, 1989; Zimmerman és Kitsantas, 2005; Pintrich, 2005). (Lásd 2. ábra)

A tervezési fázis elemei: - feladatelemzés és célkitüzés; - stratégiai feladatmegoldó lépések tervezése, - ismeretek arról, milyen kognitív taktikák léteznek az információ átalakítására; - a feladat paramétereinek ismerete; - készségekre vonatkozó önismeret - ehhez kapcsolódnak az önmotiválásra vonatkozó hiedelmek, mint például a hatékonysághit (self-efficacy); az eredményelvárások (például milyen tudást, készséget sajátít el a tanuló a feladatmegoldás által és ehhez mennyi gyakorlás szükséges); - a feladat érdekessége és értékessége (például, unalmas ugyan a feladat, de fontos nekem, hogy tanuljak); célorientáció (intrinzik-extrinzik, masterykudarckerülö-kudarcorientált) (Ryan és Deci, 2000; Covington, 2000; Smiley és Dweck, 1994).

A teljesitmény fázis magában foglalja: - a metakognitív monitorálást, vagyis a kognitív stratégiai folyamatok (gyakorlás, információszervezés, problémamegoldási próbálkozások, heurisztikák) helyességének vagy hibás voltának ellenőrzését, - a feladat nehézségének pontos becslését, - annak észlelését, hogy a pillanatnyi tudás milyen távol van a kitüzött céloktól, - annak ellenőrzését, hogy a személy milyen mértékben tudja felidézni a hosszú távú memóriából a tanultakat. Ezzel párhuzamosan a motivációs rendszer szabályozása is létrejön. A metamotivációs, akarati aspektusok elemei: 1. Figyelem kontroll: a szelektivitás fenntartása, a fel- 
adathoz illő ingerek szándékolt kiemelése és a zavaró ingerek mellőzése. 2. Érzelmi kontroll: a negatív érzelmek áthangolása, a támogató érzelmek erösítése. 3. Motiváció kontroll: önjutalmazó aktivitás alkalmazása, büszkeség elöre vetítése, a küzdelem feladása esetén a lehetséges hátrányok elképzelése, fantáziaképek és gondolatok. 4. Környezeti kontroll: a környezeti feltételek befolyásolása (idő, hely megválasztása, társas környezet, segítség igénybe vétele), más megfogalmazásban az erőforrások szabályozása (Rheinberg et al., 2005; Kuhl és Kraska,1989; Kuhl, 2000; Higgins, 1987; Henderson és Dweck, 1990; Dweck,1985; Csíkszentmihályi, 2001; Corno és Rohrkemper, 1985).
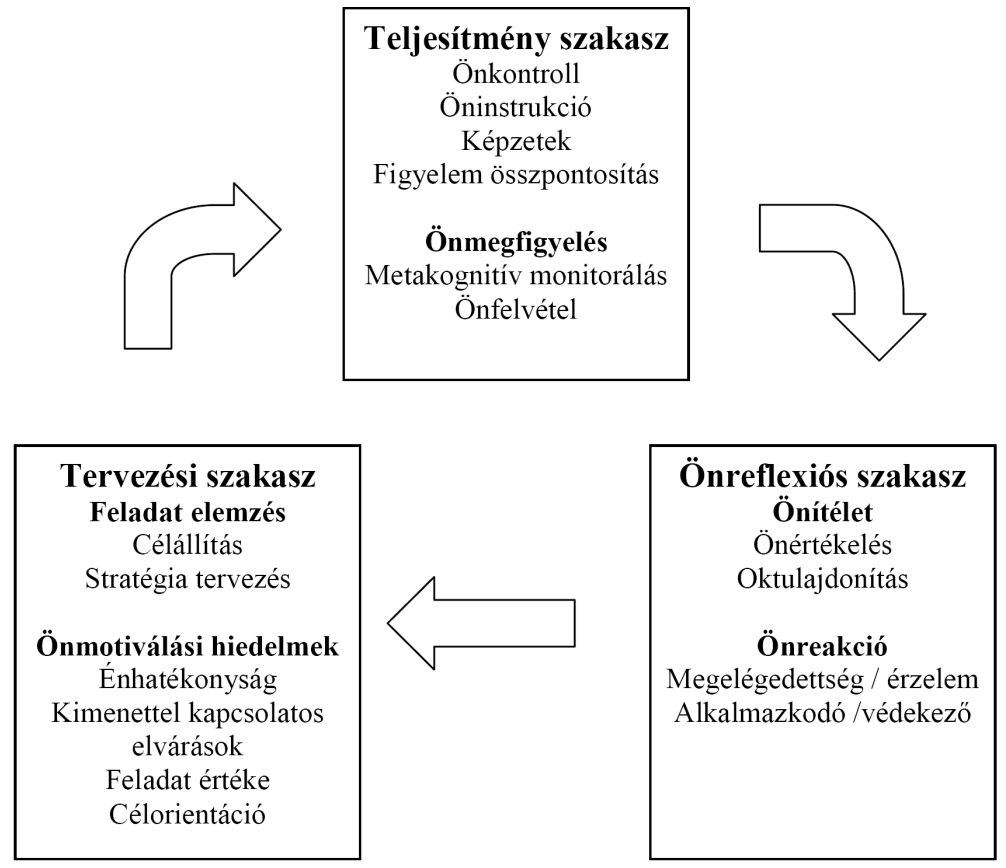

2. ábra: Az önszabályozó tanulás háromfázisú folyamata Zimmerman és Kitsantas (2005) nyomán

Az önreflexiós fázis: - a feladatvégzés tapasztalatai alapján megvalósul a hibák és az erős oldalak elemzése, ezen kívül azonban az egyén a saját énjére vonatkozó értékeléseket is végez - attribúciókat alakít ki, a tapasztalatokat magyarázza oki tulajdonítás révén, - ennek következtében elégedettség vagy önleértékelés, elégedetlenség jön létre (Higgins, 1987; Weiner, 1990).

Az önszabályozó tanulás a mindennapi tanulási folyamatot a maga bonyolultságában mutatja be, a megismerő folyamatok és a motivációs mechanizmusok összekap- 
csolódására támaszkodva. E nézőpont szerint a pedagógus feladata a metakognitív és metamotivációs stratégiák fejlesztésének elősegítése a tanulás folyamatában (Winne és Penny, 2005). Egy hazai vizsgálatban 314 budapesti, 7-12. évfolyamos gimnazista tanulási és motivációs stratégiáit vizsgáltuk Pintrich, „A tanulás motivált stratégiái" kérdőívének (MSLQ) egy módosított változatával (Katona és Szitó, 2006; Pintrich et al., 1991; Kivinen, 2003), melynek skálái az önszabályozó tanulás elemeit tartalmazzák. A regresszióanalízisre épülő adatfeldolgozás révén a feladat szubjektív értéke vonatkozásában azt találtuk, hogy az életkor előrehaladtával a jobb érdemjegy megszerzése iránti igény nő, míg a tantárgyi ismeret tartalma és a problémamegoldás folyamata iránti érdeklődés, vagyis a tanulási feladatok intrinzik értéke csökken. Ez az eredmény magyarázható az öndeterminációs elmélet alapján, mely azt jósolja, hogy az erősen kontrollált és választási lehetőségek nélküli tanulási környezet erős extrinzik (külső) és gyenge intrinzik (belső) feltételeket teremt a szabályozás alakulásában. Szoros pozitív kapcsolat van ugyanakkor az énhatékonyság hiedelmek, az erőfeszítés és az érdemjegyek között az életkortól függetlenül, ennél fogva e két motivációs elem extrinzik kimenethez kapcsolódik, jóllehet ez nem magától értetődő, mert intrinzik kimenethez is tartozhatnának. A hierarchikus klaszteranalízis pedig olyan összefüggésre mutat rá, miszerint föként az alacsonyabb (közepes) érdemjegyü tanulók használnak tanulmányi feladataik elvégzése során metakognitív és metamotivációs stratégiákat, a magas érdemjegyüek csak ritkán vagy saját válaszaik alapján tudatosan egyáltalán nem. A metakognitív és metamotivációs stratégiák használata, úgy tünik, csak hiányállapotok korrigálását szolgálja. $\mathrm{Az}$ itt leírt eredményt úgy értelmezzük, hogy az erősen kontrolláló tanulási környezethez nagy valószínűséggel az entitás elméleten alapuló képességfelfogás kapcsolódik. Jó teljesítmény elérése egy eleve meglévő, változtathatatlan képesség által jöhet létre, ha valaki azonban metastratégiák használatára „kényszerül”, olyan benyomást kelthet másokban mintha „fogyatékossága” lenne. Ez az eredmény egy adott kontextussal rendelkező tanulási környezet értékrendjét és hétköznapi hiedelemrendszerét tükrözi, azonban meghatározza a metastratégiák oktatására és fejlesztésére vonatkozó erőfeszítések sikerét, az e területekhez tartozó kulcskompetenciák fejlesztésének hatékonyságát.

A szükségletek hierarchiájától a motivációs stílusokon át a cselekvéselméletig és a tanulás önszabályozásáig ívelő motivációs elméletek egyre finomabb hangolással közelítik meg és értelmezik az iskolai tanulás valódi természetét. Eközben hangsúlyoznak olyan értékpreferenciákat, mint az önaktualizáció, az intrinzik érték, a pozitív önértékelés, a magas hatékonysághit, a mastery-orientáció, a metastratégiák használata, a képességek növekedésének elmélete, melyek elsősorban a tanulóközpontú tanulást támogatják a tanárközpontú tanulással szemben. Valódi gazdagodást jelentene azonban az iskolaközeli motivációs kutatások és a hozzájuk kapcsolódó elméletek számára, ha a tanulókra vonatkozó motivációs jellemzők egyre szerteágazóbb megismerése olyan törekvésekkel párosulna, amelyek feltár- 
nák, hogy az eltérő oktatási programok, ezen belül az egyes iskolák és a különbözö tanulási folyamatok facilitálásában résztvevő pedagógusok milyen tanulási környezetet teremtenek és milyen motivációs stratégiákat alkalmaznak, amikor a diákokat bevonják a különféle tanulási tevékenységekbe.

\section{Irodalom}

Anderson, C. A., Bushman, B. J. (2002): Human aggression. Annual Review of Psychology, (53) $1,27-51$.

Anderson, R. - Manoogian, S. T. - Reznick, J. S. (1976): The undermining and enhancing of intrinsic motivation in preschool children. Journal of Personality and Social Psychology, (34) 5, 915-922.

Bábosik István (2004): A pedagógus személyiségének és magatartásának szerepe a nevelési folyamatban. Mester és Tanitvány, 4. sz. 11-25.

Bandura, A. (1986): Social foundations of thought and action: A social cognitive theory. Prentice Hall, Englewood Cliffs, NJ.

Bembenutty, H. (2008): Academic delay of gratification, self-regulation of learning, gender differences, and expectancy-value. Personality and Individual Differences, (46) 3, $347-352$.

Bowlby, J. (1979): The making and breaking of affectional bonds. Tavistock, London.

Boykin, A. W., Ellison, C. M., Dillihunt, M. L., Tyler, K. M. (2005): Examining classroom learning preferences among elementary school students. Social Behavior and Personality, (33) 7, 699-708.

Braverman, R. T. (2001): Applying resilience theory to prevention of adolescent substance abuse. Spring, The 4-H Center for Youth Development, University of California, Davis, $1-11$.

Brophy, J. E. (1978): Interactions between learner characteristics and optimal instruction. In: Bar-Tal Saxe (Ed.): Social Psychology of Education. Hemisphere Publishing Corporation, Washington, 135-148.

Brophy, J. E. (1981): Teacher praise: a functional analysis. Review of Educational Research, (51) 1, 5-32.

Brophy, J. E. (1983): Research on the self-fulfilling prophecy and teacher expectations. Journal of Educational Psychology, (75) 5, 631-661.

Chung, I., Hill, K. G., Hawkins, J. D., Gilchrist, L. D., Nagin, D. S. (2002): Childhood predictors of offense trajectories. Journal of Research in Crime and Delinquency, (39) 1, 60-90.

Cole, M., Cole, S. (1997): Fejlödéslélektan. Osiris Kiadó, Budapest.

Coleman, J. S. (1976): A serdülök szubkultúrája és az iskolai teljesítmény. In: Pataki Ferenc (szerk.): Pedagógiai szociálpszichológia. Gondolat, Budapest, 588-615.

Corno, L., Rohrkemper, M. (1985): The intrinsic motivation to learn in classrooms. In: Ames, C., Ames, R. (Eds.): Research on motivation in education. (2) Academic Press, Inc. New York, 53-92. 
Covington, M. V. (2000): Goal theory, motivation, and school achievement: An Integrative Review. Annual Review of Psychology, (51) 1, 171-200.

Csapó Benő (1978): A mastery learning elmélete és gyakorlata. Magyar Pedagógia, 1. sz. $60-73$.

Csíkszentmihályi Mihály (2001): Flow. Az áramlat. Akadémiai Kiadó, Budapest.

Csikszentmihalyi, M., Rathunde, K. (1993): The measurement of flow in everyday life: Toward a theory of emergent motivation. In: Jacobs, J. E. (Ed.): Developmental perspectives on motivation. University of Nebraska Press, Lincoln, 57-97.

deCharms, R. (1968): Personal causation. Academic Press, New York.

Deci, E. L., Ryan, R. M. (1985): Intrinsic motivation and self-determination in human behavior. Plenum, New York.

Deci, E. L., Koestner, R., Ryan, R. M. (1999): A meta-analytic review of experiments examining the effects of extrinsic rewards on intrinsic motivation. Psychological Bulletin, (125) 1, 627-668.

Dweck, C. S., Leggett, E. L. (1988): A social-cognitive approach to motivation and personality. Psychological Review, (95) 2, 256-273.

Dweck, C. S. (1985): Intrinsic Motivation, Perceived Control, and Self-evaluation Maintenance: An Achievement Goal Analysis. In: Ames, C. - Ames, R. (Eds.): Research on motivation in education. (2) Academic Press, Inc. New York, 289-306.

Eggen, P., Kauchak, D. (2001): Educational Psychology. Merrill-Prentice Hall, New Jersey.

Festinger, L. (1972): A kognitív disszonancia elmélete. In: Hunyady György (szerk.): Szociálpszichológia. Gondolat, Budapest, 75-83.

Fisher, E. J. (2005): Black Student Achievement and the Oppositional Culture Model. Journal of Negro Education, (74) 2, 201-210.

Golnhofer Erzsébet (1998): A pedagógiai értékelés. In: Falus Iván (szerk.): Didaktika. Nemzeti Tankönyvkiadó, Budapest, 392-417.

Gray, P., Feldman, J. (2004): Playing in the zone of proximal development: Qualities of self-directed age mixing between adolescents and young children at a democratic school. American Journal of Education, (110) 2, 108-145.

Hallinger, P., Murphy, J. F. (1986): The social context of effective schools. American Journal of Education, (94) 3, 328-355.

Harris, J. M., Som, A., McPherson, M., Dees, J. E. M. E. G. (2008): Risk factors in child maltreatment: A meta-analytic review of the literature, Aggression and Violent Behavior, doi:10.1016/j.avb.2006.03.006

Harter, S. (1992): Visions of self: beyond theme in the mirror. In: Jacobs, J. (Ed.): $\mathrm{Ne}$ braska Symposium on Motivation. 40. University of Nebraska Press, Lincoln.

Heider, F. (1958): The psychology of interpersonal relations. Wiley, New York.

Henderson, V. L., Dweck, C. S. (1990): Motivation and achievement. In: Feldman, S. S. Elliott, G. R. (Eds.): At the threshold: The developing adolescent. MA: Harvard University Press, Cambridge, 308-329. 
Higgins, E. T. (1987): Self-discrepancy: a theory relating self and affect. Psychological Review, (94) 3, 319-340.

Houde, J. (2006): Andragogy and Motivation: An Examination of the Principles of Andragogy through Two Motivation Theories. Academy of Human Resource Development International Conference (AHRD) (Columbus, OH, Feb, 22-26, 2006) 90-97.

Jimerson, S. R., Campos, E., Greif, J. L. (2003): Toward an Understanding of Definitions and Measures of School Engagement and Related Terms. The California School Psychologist, (8) 1, 7-27.

Johnson, D. W. (1979): Educational Psychology. Prentice Hall, Englewood Cliffs, New Jersey.

Józsa Krisztián (2002): Az elsajátítási motiváció pedagógiai jelentősége. Magyar Pedagógia. 1. sz. 79-104.

Katona N., Szitó, I. (2006): Self-regulated learning in a control-oriented environment. ISPA The $26^{\text {th }}$ International School Psychology Colloquium, konferencia elöadás.

Kelman, H. C. (1972): A szociális befolyásolás három folyamata. In: Hunyady György (szerk.): Szociálpszichológia. Gondolat Kiadó, Budapest, 47-59.

Kim, M. J. (2006): Culture-specific psychoeducational induction talk as an intervention to increase service utilization among minority populations: the case of Korean American. Vistas. American Counselling Association.

Kivinen, K. (2003): Assessing Motivation and the Use of Learning Strategies by Secondary Schoool Students in Three International Schools. Disszertáció, Faculty of Education of the University of Tampere.

Kroger, J. (2007): Identity development. Sage, London.

Kuhl, J. (2000): The volitional basis of personality systems interaction theory: applications in learning and treatment contexts. International Journal of Educational Research, (33) 7-8, 665-703.

Kuhl, J., Kraska, K. (1989): Self-regulation and metamotivation: Computational mechanisms, development, and assessment. In: R. Kanfer, R. - Ackerman, P. L. -Cudek, R. (Eds.): Abilities, motivation, and methodology: The Minnesota Symposium on Individual Differences. Lawrence Erlbaum Associates Inc., Hillsdale, NJ., 343-374.

Kwok, O., Hughes, J. N., Luo, W. (2007): Role of resilient personlaity on lower achieving first grade students' current and future achievement. Journal of School Psychology, (45) 1, 61-82.

M. Nádasi Mária (2004a): A szöveges értékelés szerepe a nevelés-oktatás folyamatában. In: Hunyady Györgyné - M. Nádasi Mária (szerk.): Osztályozás? Szöveges értékelés? Dinasztia Tankönyvkiadó, Budapest, 40-43.

M. Nádasi Mária (2004b): Az értékelés pedagógiai kérdései. In: Hunyady Györgyné - M. Nádasi Mária (szerk.): Osztályozás? Szöveges értékelés? Dinasztia Tankönyvkiadó, Budapest, 34-39.

Maslow, A. (1943): A theory of human motivation. Psychological Review, (50) 3, 370-396.

Maslow, A., Lowery, R. (Ed.) (1998): Toward a psychology of being. Wiley \& Sons, New York. 
McInerney, D. M., Swisher, K. G. (1995): Exploring navajo motivation in school settings, in: Journal of American Indian Education, (34) 3, 127-136.

Meichenbaum, D. H., Goodman, J. (1971): Training Impulsive Children to Talk to Themselves: A Means of Developing Self-Control. Journal of Abnormal Psychology, (77) 2, 115-126.

Molnár Éva (2000): Tanulmányok az önszabályozó tanulásról. Iskolakultúra, 2. sz. 101-103.

Molnár Éva (2002): Önszabályozó tanulás: nemzetközi kutatási irányok és tendenciák. Magyar Pedagógia, 1. sz. 63-77.

Murray, C., Greenberg, M. T. (2001): Relationships with teachers and bonds with school: Social emotional adjustment correlates for children with and without disabilities. Psychology in the Schools, (38) 1, 25-41.

Nagy József (2000): XXI. századi nevelés. Osiris Kiadó, Budapest.

Németh Erzsébet (1999): Hogyan jutalmazzunk? In: Fehér Irén (szerk.): Pedagógia és pszichológia. Comenius Bt., Pécs, 241-253.

Nisson, J. E., Paul, B. D., Lupini, L. N., Tatem, B. (1999): Cultural differences in perfectionism: a comparison of African American and White College Students. Journal of College Student Development, (40) 3-4, 141-150.

Ormrod, J. E. (2000): Educational Psychology. Merrill, New Jersey.

Pintrich, P. R., Smith, D. A., Garcia, T., McKeachie, W. J. (1991): A manual for the use of the Motivated Strategies for Learning Questionnaire (MSLQ). National Center for Research to Improve Postsecondary Teaching and Learning, University of Michigan, Ann Arbor.

Pintrich, P. R. (2005): The role of goal orientation in self-regulated learning. In: Boekaerts, M. - Pintrich, P. R. - Zeidner, M. (Eds.): Handbook of self-regulation. Academic Press, New York, 451-502.

Pintrich, R. R., DeGroot, E. V. (1990): Motivational and self-regulated learning components of classroom academic performance, Journal of Educational Psychology, (82) 1, 33-40.

Réthy Endréné (2002): A kognitív és motivációs önszabályozást kialakító oktatás. Iskolakultúra, 2. sz. 3-12.

Rheinberg, F., Vollmeyer, R., Rollet, W. (2005): Motivation and action in self-regulated learning. In: Boekaerts, M. - Pintrich, P. R. - Zeidner, M. (Eds.): Handbook of selfregulation. Academic Press, New York, 503-529.

Ryan, R. M., Connell, J. P. (1989): Perceived locus of causality and internalization. Journal of Personality and Social Psychology, (57) 5, 749-761.

Ryan, R. M., Deci, E. L. (2000): Self-determination theory and the facilitation of intrinsic motivation, social development and well-being. American Psychologist, (55) 1, 68-78.

Santrock, J. W. (2008): Educational Psychology. McGraw Hill, Boston.

Shade, B. J. (1982): Afro-American Cognitív Style: A Variable in School Success? Review of Educational Research, (52) 2, 219-244.

Sinclair, M. F., Christenson, S. L., Lehr, C. A., Anderson, A. R. (2003): Facilitating Student Engagement: Lessons Learned from Check \& Connect Longitudinal Studies. The California School Psychologist, (8) 1, 29-41. 
Smiley. P. A., Dweck, C. S. (1994): Individual differences in achievement goals among young children. Child Devevelopment, (65) 6, 1723-1743.

Smith, R. M. (1982): Learning how to learn. Cambridge, The Adult Education Company, New York.

Stipek, D., Gralinski, J. H. (1996): Children's beliefs about intelligence and school performance. Journal of Educational Psychology, (88) 3, 397-407.

Stith, S. M., Liu, T., Davies, L. C., Boykin, E. L., Alder, M. C., Jimerson, S. R., Campos, E., Greif, J. L. (2003): Toward an Understanding of Definitions and Measures of School Engagement and Related Terms. The California School Psychologist, (8) 1, 7-27.

Strinski, S. M., Ireland, M., Michaud, P., Narring, F., Resnick, M. D. (2000): Protective correlates of stages in adolescent substance abuse: A Swiss national study. Journal of Adolescent Health, (26) 6, 420-427.

Stronge, J. H. (2002): Qualities of effective teachers. ASCD, Alexandria.

Szitó Imre, Katona Nóra (2004): A tanári tekintély a szociálpszichológia nézőpontjából. Mester és Tanítvány, 4. sz. 36-49.

Szitó Imre, Katona Nóra (2007): Hátrányos helyzet, veszélyeztetettség és iskolai siker. Mester és Tanitvány, 7. sz. 40-66.

Tedeschi, J. T., Lindskold, S. (1976): Social psychology. John Wiley and Sons, New York.

Thomas, M. R. (2001): Recent Theories of Human Development. Sage, London.

Vajda Zsuzsanna, Kósa Éva (2005): Neveléslélektan. Osiris Kiadó, Budapest.

Ventegodt, S., Merrick, J., Andersen, N. J. (2003): Quality of Life Theory I. The IQOL Theory: An Integrative Theory of the Global Quality of Life Concept. TheScientificWorldJOURNAL, (3) 10, 1030-1040.

Vigotszkij, L. Sz. (1971): A magasabb pszichikus funkciók fejlödése. Gondolat Kiadó, Budapest.

Walters, C. A., Pintrich, P. R., Karbenich, S. A. (2003): Assessing academic self-regulated learning. Conference on Indicators of Positive Development, Washington.

Wei, M., Mallinckrodt, B. (2004): Maladaptive perfectionism as a predictor and moderator between adult attachment and depressive mood. Journal of Counseling Psychology, (51) 2, 201-212.

Weiner, B. (1979): A theory of motivation for some classroom experiences, Journal of Educational Psychology, (77) 1, 3-25.

Weiner, B. (1990): History of motivation research in education. A theory of motivation for some classroom experiences. Journal of Educational Psychology, (82) 4, 616-622.

Wentzel, K. R. (2005): Peer relationships, motivation, and academic performance at school. In: Elliott, A. J. - Dweck, C. S. (Eds.): Handbook of Competence and Motivation. The Guilford Press, New York, 279-297.

Wigfield, A., Eccles, J. S. (2000): Expectancy-Value Theory of Achievement Motivation. Contemporary Educational Psychology, (25) 68-81.

Winne, P. H., Penny, R. E. (2005): Measuring Self-regulated Learning. In: Boekaerts Pintrich - Zeidner (Eds.) Handbook of self-regulation. Academic Press, New York, $531-566$. 
Woolfolk, A. (2001): Educational Psychology. Allyn and Bacon, London.

Zimmerman, B. J. (1989). A Social Cognitive View of Self-regulated Academic Learning. Journal of Educational Psychology, (81) 3, 329-339.

Zimmerman, B. J., Kitsantas, A. (2005): Dimension of presonal competence: self-regulated learning and practice. In: Elliot, A. J. - Dweck, C. S. (Eds.): Handbook of competence and motivation. The Guilford Press, London. 509-527. 